\title{
MARX E O PENSAMENTO INVERTIDO: SOBRE A QUESTÃO DA CONTINGÊNCIA DA POLÍTICA
}

\author{
MARX Y EL PENSAMIENTO INVERTIDO: SOBRE LA CUESTIÓN DE LA \\ CONTINGENCIA DE LA POLÍTICA
}

\section{MARX AND INVERTED THINKING: ON THE QUESTION OF THE POLICY CONTINGENCY}

\author{
DOI: https://doi.org/10.9771/gmed.v13i3.43499
}

\author{
Henrique Leão Coelho ${ }^{1}$
}

Resumo: O texto avança no alcance da tese da ontonegatividade da política, querendo enfatizar sua contigência histórica, isto é, práxis social assentada sobre classes e esfera irresolutiva para a emancipação humana, segundo Marx. Avança, sobretudo, em textos pouco tematizados nesse sentido, as obras de 1845-46: A Sagrada Família e A Ideologia Alemã. Embora, não se trate de um terreno a ser desprezado, dado que de sua disputa pode surgir o progresso social, o direito social, a conquista tático-defensiva, trata-se de repor a assertiva marxiana incisiva e refulgente de sua irresolubilidade e exigência inexorável da metapolítica.

Palavras-chave: Marx. Política. Especulativismo. Estado. Emancipação

Resumen: El texto avanza en el ámbito de la tesis de la ontonegatividad de la política, queriendo destacar su contingencia histórica, es decir, la praxis social basada en las clases y la esfera irresoluta para la emancipación humana, según Marx. Avanza, sobre todo, en textos poco tematizados en este sentido, las obras de 1845-46: A Sagrada Familia y A Ideologia Alemã. No es un terreno a despreciar, pues de su disputa puede surgir el progreso social, el derecho social, la conquista táctico-defensiva, pero se trata de restituir la incisiva y refulgente afirmación marxiana de su irresolubilidad y exigencia inexorable de la metapolítica.

Palabras clave: Marx. Política. Especulación. Estado. Emancipación.

Abstract: The text advances in the field of the thesis of the ontonegativity of politics, wanting to emphasize its historical contingency, that is to say, the social praxis based on classes and the irresolute sphere for human emancipation, according to Marx. It advances, principally, in texts little thematized in this sense, the texts of 1845-46: A Sagrada Família and A Ideologia Alemã. It is not a terrain to be despised, since from its dispute can emerge social progress, social right, tactical-defensive conquest, but it is a matter of restoring the incisive and refulgent Marxian affirmation of its irresolvability and inexorable demand of metapolitics.

Keywords: Marx. Policy. Epeculativism. State. Emancipation.

\section{Introdução}

Do enriquecido novelo teórico marxiano, é possível extrair delineamentos filosóficos e contribuições de maior nível de concreção que até hoje são fulcrais para explicação da realidade efetiva. Isso se dá uma vez que Marx não foi um autor de verve epistemologista, um autor banal formulador de mais um pueril e datado modelo a priori para a moda das investigações sociais. Investigador de insigne 
escrutínio, esforço e erudição, Marx infletiu à apreensão das categorias concretamente existentes, formas de ser, determinações de existência. Dessa feita, a questão epistemológica nunca ganhou um veio predominante e hipostasiado, antes, subsumida à questão ontológica, às asseverações do ser que conhece, à primazia da objetividade no exercício do conhecimento, à determinação ontoprática do pensamento e à determinação social do pensamento (CHASIN, 2009). Nesse sentido, vamos ao encalço da seminal e convictamente atual (com alguma infelicidade) obra marxiana, em período recortado, por óbvio, para esmiuçar aquilo já constatado por J. Chasin: a determinação ontonegativa da politicidade, tema já suficientemente retomado em suas linhas gerais em outros artigos (SILVA, 2013; ALBINATI, 2008; SARTORI, 2016). Basta retomar que a questão lapidada pelo filósofo brasileiro, ancorado no filósofo alemão, trata de um exame fundamental, justamente porque:

Nada ressoa mais no quadro histórico atual do que o cântico entoado pela afirmação e aperfeiçoamento da vida política, indicativo da maré montante, prática e teórica, de uma equação humanossocietária que no curto prazo já não pode mais ser melhorada, e cuja feição se equipara a uma renúncia. Acentuo que se trata de uma "renúncia e nulificação, ativa e ideal, de um propósito decisivo", nada menos do que a abdicação de um "patrimônio que nunca dantes fora abjurado". E pergunto, como quem responde, se "sofridos e maduros, estamos nos despojando, e com razão, de uma tralha de sonhos perversos, ou simplesmente, encabulados, perdidos nos desvãos de um labirinto inacabado, estamos desistindo, nada mais nada menos, do que de nós mesmos", despejando, sem qualquer cerimônia, no latão dos detritos o único complexo problemático verdadeiramente incontornável, desafiador e radical - a expectativa e a interrogante pela autoconstrução do humano. (CHASIN, 2012, p. 42)

Nesse diapasão, a política é apreendida não como atributo perene do ser social ou elemento intrínseco indelével, como, por vezes, nas teorias idealistas, foi assumido: práxis preponderante na edificação e caracterização do humano. Ao mesmo tempo, a afirmativa de seu caráter contingente é insuficiente para uma explicação, mesmo limitada, de lineamentos mais gerais. Em suma, é preciso demarcar a politicidade como assentada na configuração societária de classes, sobretudo, como administração política dos conflitos dos proprietários privados. Mesmo em sua situação mais acendrada, no "estado político acabado" (MARX, 2010a), como se tem na dicção marxiana de 1844 em Sobre a questão judaica, trata-se de um "céu estatal" que somente tangencia a sociedade civil-burguesa ao passo que a pressupõe: em outros termos, também marxianos, o citoyen é servo do bourgueois, denotando que a revolução política e a conquista da emancipação política, embora não sejam desprezíveis, consignam uma emancipação oblíqua, isto é, por meio de um “desvio" (MARX, 2010a). Em síntese, a exigência de retomar esse tema parece óbvia na medida em que o espessamento dos ideários do aperfeiçoamento político, sintomática do "complexo problemático" derrogado e substituído pela diversidade da contrafação politicisita/estatista, se configura mesmo na intelecção daqueles partidários da revolução social.

A emancipação política de fato representa um grande progresso; não chega a ser a forma definitiva da emancipação humana em geral, mas constitui a forma definitiva da emancipação humana dentro da ordem mundial vigente até aqui. Que fique claro: estamos falando aqui de emancipação real, de emancipação prática. (MARX, 2010a, p. 41)

Com isso, não se obnubila que o fenecimento das formas políticas se dá por uma extinção paulatina engendrada pela reabsorção das "forças sociais usurpadas", revolvimento e superação efetivada 
no próprio decurso da reconfiguração da base econômica. Porém, a complexidade e as particularidades de cada reconfiguração revolucionária não permitem crispar a letra marxiana fornecendo a tergiversação mais gostosa e conveniente. Sobremaneira, só adotando uma mendaz vista grossa e um ardiloso descuido com a obra marxiana para obscurecer que:

Uma revolução "social" com alma política pode ser um contrassenso complexo, caso o "prussiano" entenda por revolução "social" uma revolução "social" em contraposição a uma revolução política, emprestando, não obstante, à revolução social uma alma política em vez de uma alma social. Ou uma "revolução social com alma política" nada mais é que uma paráfrase daquilo que, de resto, foi denominado de "revolução política" ou "revolução pura e simples". Toda e qualquer revolução dissolve a antiga sociedade; nesse sentido, ela é social. Toda e qualquer revolução derruba o antigo poder; nesse sentido, ela é política. O "prussiano" faça sua escolha entre a paráfrase e o contrassenso! Contudo, na mesma medida em que uma revolução com alma política é parafrástica ou absurda, uma revolução política com alma social faz sentido. A revolução como tal - a derrubada do poder constituído e a dissolução das relações antigas - é um ato político. No entanto, sem revolução o socialismo não poderá se concretizar. Ele necessita desse ato político, já que necessita recorrer à destruição e à dissolução. Porém, quando tem início a sua atividade organizadora, quando se manifesta o seu próprio fim, quando se manifesta a sua alma, o socialismo se desfaz do seu invólucro político. (MARX, 2010b, p. 52)

Doravante, o texto avança no alcance da tese da ontonegatividade da política, querendo enfatizar sua contingência histórica, práxis social assentada sobre classes e esfera irresolutiva para a emancipação humana (MARX, 2010a). Avança, sobretudo, em textos pouco tematizados nesse sentido, as obras de 1845-46: A Sagrada Família e A Ideologia Alemã. Ao contrário do que se vê abastadamente em diversos acólitos e asseclas da politicidade, arautos da "nova política", arejadores do mofo com mais dele próprio (sob capas e versões pretensamente arrojadas), as promessas de panaceia - politicista afogam as exigências dos trabalhadores, que ganham hoje para perder em dobro amanhã. Embora não se trate, como sobredito, de um terreno a ser desprezado, dado que de sua disputa pode abrolhar o progresso social, o direito social, a conquista tático-defensiva, trata-se de repor a assertiva incisiva e refulgente de sua irresolubilidade, exigência inexorável da metapolítica (CHASIN, 2001), da política levada aos limites podendo desdobrar em sua superação a partir da efetivação da "alma social" da revolução (MARX, 2010b), enfim, a circunscrição de que:

A democracia, não por constituir a forma de liberdade originária da sociabilidade do capital, mas por ser a forma acabada da liberdade limitada, tem de ficar para trás, quando se trata de ampliar ou expandir, de dar prosseguimento à edificação da própria liberdade. Tem de ser ultrapassada como desobstrução da rota que conduz a níveis mais elevados e elaborados de liberdade ou emancipação. Caminho que não é, nem pode ser, a dilatação da liberdade política, uma vez que esta - a democracia - é a sua forma final; ou seja, não há politicamente, um para além da democracia, ao mesmo tempo que ela é uma figura que estaciona no aquém da forma "final" da liberdade. Ou seja, é uma forma particular de liberdade, homóloga à particularidade do modo de produção do capital, e, enquanto tais, formas transitórias de produção e liberdade. (CHASIN, [200-], p. 51)

\section{Marx e o pensamento invertido: perquirição da ontonegatividade da política em A Sagrada}

\section{Família e A Ideologia Alemã}


Partindo das elucubrações extremamente valiosas dos Manuscritos de 44, temos a tônica da crítica ontológica de Marx bem exposta por ele próprio. Crítica que se dirige à especificidade de cada esfera do ser social criticada, que não obstante, não se encerra em qualquer hipóstase. Assume a tarefa do delineamento do ser-propriamente-assim de cada esfera, mas o faz tendo em conta a interconexão dos complexos, evidenciando a realidade efetiva como totalidade articulada social. Ademais, crítica ontológica que em seu procedimento caracterizante atinge, cotejando com a razão de ser de cada esfera objetiva, as teorias especulativas referentes, isto é, a teoria hegeliana, as assertivas neo-hegelianas e os arraiais idealistas dos economistas políticos.

Por conseguinte, farei sucessivamente em brochuras distintas e independentes, a crítica do direito, da moral, da política etc., e tratarei, por último de expor em um trabalho particular a conexão de conjunto, a relação das distintas partes entre si, assim como a crítica da elaboração especulativa daquele material. Eis o motivo porque o estado, o direito, a moral, a vida civil etc. só será abordada na medida em que a economia política lida expressamente com estas questões. (MARX, 1999, p.1)

Dessa feita, as linhas que se seguem transitam na plataforma erguida por Marx nos anos 40: as críticas ontológicas interrelacionadas e o seu delineamento filosófico original, o abrolhar de sua concepção materialista da história refringente ao materialismo naturalista de Feuerbach, aquele que teria proporcionado uma "revolução teórica" (MARX, 1999) dilapidando a sedimentação renitente do hegelianismo nas penas dos pós-hegelianos. Se é certo que já no ano de 45, o autor de Trier passou a meandrar seus elogios a Feuerbach, ou seja, do afastamento desse autor dos neo-hegelianos incidiu na aproximação relativa a eles (ENDERLE, 2000), demonstrando a sobredita fragilidade e dependência idealista do materialismo naturalista feuerbachiano, não é prescindível insistir que Feuerbach condensou uma prototípica crítica ao autoengendramento logicista hegeliano: isso se marca, por exemplo, na retomada seminal de Marx de que “o ser é uno com o que é”. A aproximação com Feuerbach e seu referente ultrapassamento filosófico instalam-se, portanto, no itinerário marxiano como aperfeiçoamento da apreensão dos lineamentos mais gerais do ser social, abstrações razoáveis de mais largo alcance dessa instância ontológica, assim como a subsequente escavação da objetividade do complexo econômico capitalista, "a anatomia da sociedade civil". Dessa forma, a crítica à demiurgia de um "universal abstrato", ao espírito autoposto, à consciência autoengendrada, enfim, a toda espécie teórica de negligência com os nexos e relações atinentes à materialidade social vão dando corpo à "virada marxiana de Marx" (CHASIN, 2009), à instauração teórica de seu delineamento filosófico e de seu escrutínio propriamente científico.

O texto em tela, de maneira mais estreita, mas vincada intimamente ao contexto supracitado, pretende dissecar de que maneira a crítica de Marx à politicidade e às “teorias da politicidade” prosseguem em textos de 45-46. Nesse intuito, não é de surpreender que devamos remeter às demais críticas ontológicas por vezes, já que, resta claro, se trata de críticas que se armam de modo interrelacionado a partir de uma concomitante instauração teórica crescentemente adensada.

Em A Sagrada Família, Engels não é nada furtivo no exercício crítico de seu prólogo. O "primeiro marxista" abre o escrito constatando que o humanismo tem como inimigo, na Alemanha, o perdulário idealismo. Isso porquanto esse último troca o ser humano real, o indivíduo concretamente existente, pela Ideia, pela Consciência, pela Lógica. O autor, preambulando a malha teórica marxiana, 
afirma a tônica reiterada por Marx nos textos anteriores, isto é, que a lavra dos irmãos Bauer, em sua acrisolada "Crítica crítica", permanece na renitência da especulação hegeliana, isto é, não conseguem suprimir os insumos teológico-críticos. Friedrich Engels, em enérgico sarcasmo elucidativo, ironiza que a "crítica crítica" se coloca acima da "massa", mas dotada de compaixão por ela, envia seu filho unigênito, o salvador da massa brutalizada (ENGELS, 2003).

A Crítica crítica, em sua odisseia salvacionista, chega aos cimos da humildade: utiliza jargões populares como forma de descer à massa para que ela suba. Chega até ao "absurdo" de utilizar línguas estrangeiras. Há tanta "humildade" por parte da Crítica crítica que seus autores fazem até abstenção de conteúdo, arremata Engels (2003). Nesse diapasão, a crítica neo-hegeliana é o suprassumo orgulhoso da abstratividade, o revolvimento da Ideia que permanece em si mesma, a putrefação da "crítica teológica" (MARX, 1999). A Crítica crítica se coloca, dessa feita, como salvadora da massa, por conseguinte, repelindo na massa trabalhadora a qualidade de salvadora de si. A crítica dos neo-hegelianos, por conseguinte, está encerrada em si mesma, se despe da necessidade de esquadrinhar a objetividade social da qual trata e, na sua função missionária e idealista ativa, admite a modificação das categorias existentes como evolução ou evolver da autoconsciência. Não por acaso, a Crítica crítica se mantém no horizonte da abstratividade política, como veremos à frente.

$\mathrm{Na}$ realidade há, nas fábricas inglesas, todas as gradações de salário, de um e meio xelim a 40 xelins e inclusive mais; na Crítica paga-se apenas um salário ao trabalhador: 11 xelins. Na realidade a máquina substitui o trabalho manual; na crítica ela substitui o ato de pensar. $\mathrm{Na}$ realidade uma união dos trabalhadores com o objetivo de aumentar o salário é permitida na Inglaterra; mas na Crítica ela é proibida, uma vez que a massa tem, ela mesma, de perguntar à Crítica, se quiser se permitir tomar uma atitude. $\mathrm{Na}$ realidade o trabalho na fábrica fatiga de maneira significativa o trabalhador e origina enfermidades típicas - há, inclusive, várias obras medicinais que tratam exclusivamente dessas enfermidades; na crítica "o esforço excessivo não impede nem estorva o trabalho, pois a força é empreendida toda ela pela máquina". Na realidade a máquina é uma máquina; na Crítica ela é dotada de vontade, pois, uma vez que ela não descansa, o trabalhador também não pode descansar e torna-se súdito de uma vontade estranha. (ENGELS, 2003, p. 22)

Doravante, se tem que "Os socialistas franceses afirmam: O trabalhador faz tudo, produz tudo, e apesar disso não tem nenhum direito, nenhuma propriedade, enfim, não tem nada". Por sua vez, "A Crítica crítica responde através da boca do senhor Edgar, a Quietude do conhecer personificada: Para poder criar tudo, é necessária uma consciência mais forte do que a consciência do trabalhador". Advogando pelo seu distinto açambarcamento da verdade, a verdade da Crítica é que "O trabalhador não faz nada, por isso não tem nada", e que "ele não faz nada porque seu trabalho é sempre, permanentemente, um trabalho concreto, diário, limitado apenas a suas necessidades mais pessoais" (ENGELS, 2003, p. 29). De um lado, os arautos da verdade, da "substância", do outro, a fragilidade, humanidade exangue em verdadeira humanidade. Aos trabalhadores, por conseguinte, cabe a desconfiança, a massificação, a incapacidade, à Crítica crítica, a posse da verdade.

Os Críticos críticos, fronteira da verdade, não acreditam na "massa" como elemento modificador, logo, “superador”. Porém, como demarca o autor comunista de Trier, é no proletariado que está encarnada a desumanização aguda do capitalismo, a alienação entificada na sua faceta mais taciturna, 
decomposta, corrompida; sua condição histórica é a de ser "despossuído" da destinação de suas próprias capacidades, objetivação depauperada da divisão social do trabalho em sua forma atual, exteriorização de vida dependente e rebotalhizada, aliançada à fruição embotada, atrofiada (MARX, 1999). Assim, “Trata-se do que o proletariado é e do que ele será obrigado a fazer historicamente de acordo com o seu ser. Sua meta e sua ação histórica se acham clara e irrevogavelmente predeterminadas por sua própria situação de vida” e, objetivamente, “por toda a organização da sociedade burguesa atual”. E “nem sequer é necessário deter-se aqui a expor como grande parte do proletariado inglês e francês já está consciente de sua missão histórica e trabalha com constância no sentido de elevar essa consciência à clareza completa" (MARX, 2003, p. 49). Marx, dessa feita, não conjura com a teoria política, não expecta da politicidade a “consciência” que se eleva “à clareza completa”. No seu egrégio rubor e compreensão teórica, degreda qualquer anódino politicista como panaceia, porque, sobretudo, despede-se de qualquer hipertrofia da consciência ou qualquer demiurgia da abstratividade. Vê-se, desde já, de modo claro, o anelamento entre "meta histórica" e elevação de sua consciência não como aperfeiçoamento hipostasiado da consciência, nem tributo ao novelo político, mas possibilidade objetivamente posta pela "organização da sociedade burguesa atual" porquanto a elevação de consciência se dá de "acordo com o seu ser", com sua posição na configuração objetiva.

Segundo a Crítica crítica, todo o mal reside apenas no modo de "pensar" do trabalhador. É certo que os trabalhadores ingleses e franceses formaram associações nas quais não são apenas suas necessidades imediatas enquanto trabalhadores, mas também suas necessidades enquanto homens as que formam o objeto de seus mútuos ensinamentos e nas quais se exterioriza, ademais, uma consciência bastante ampla e cuidadosa sobre a força "monstruosa" e "imensurável" que nasce de sua cooperação. Mas esses trabalhadores massivos e comunistas, que atuam nos ateliers de Manchester e Lyon, por exemplo, não creem que possam eliminar, mediante o "pensamento puro", os seus senhores industriais e a sua própria humilhação prática. Eles sentem de modo bem doloroso a diferença entre ser e pensar, entre consciência e vida. Eles sabem que propriedade, capital, dinheiro, salário e coisas do tipo não são, de nenhuma maneira, quimeras ideais de seu cérebro, mas criações deveras práticas e objetivas de sua própria autoalienação, e que portanto só podem e devem ser superadas de uma maneira também prática e objetiva, a fim de que o homem se torne um homem não apenas no pensamento e na consciência, mas também no ser massivo e na vida. A Crítica crítica, pelo contrário, quer fazê-los crer que deixarão de ser trabalhadores assalariados na realidade apenas com o fato de superar em pensamento o pensamento do trabalho assalariado, apenas com o fato de deixar de se considerarem trabalhadores assalariados em pensamento (MARX, 2003, p. 66)

Dessa feita, a medida teórica neohegeliana é a urdidura da crítica "pura", o esbanjamento perdulário do pensamento, que não ousa se ajoelhar e descer à materialidade e que não vive com a cabeça sensível no mundo, mas com a cabeça etérea. Não suprime o Idealismo de Hegel e, decerto, repaginam e reforçam uma consideração subjetivista da "Verdade", criando-se uma metafísica mais oculta e presunçosa. Para esses autores, trata-se de um espírito evolvente que afastará as ilusões e ignomínias da massa, condição de desvelamento portada pelos próprios Críticos críticos que, em sua superioridade indelével (e injustificável), sobrevoam a vida material da massa acrítica para conduzi-la à solução racional do espírito. Enfim, resta claro, para os Críticos críticos a "massa é o adversário do espírito". É evidente, dessa feita, que a "massa" não passa, no fundo, de mais uma personificação abstrata, abantesma esculpido 
pelo logicismo dos Críticos críticos. Dessa forma, Marx resgata a Razão, a Ideia, o vir-a-ser do Espírito Absoluto presente no Idealismo Objetivo de Hegel do qual antes de se afastarem, os pós-hegelianos realçam:

A concepção hegeliana da História pressupõe um espírito abstrato ou absoluto, que se desenvolve mostrando que a humanidade apenas é uma massa que, consciente ou inconscientemente, lhe serve de suporte. Por isso ele faz com que, dentro da História empírica, exotérica, se antecipe uma História especulativa, esotérica. A História da humanidade se transforma na História do espírito abstrato da humanidade que, por ser abstrato, fica além das possibilidades do homem real. (MARX, 2003, p. 102)

Sem edulcorar, Marx assevera que a crítica crítica é "um animal ruminante que mastiga os restos hegelianos" (MARX, 2003, p. 122). A Questão judaica de Bauer volta à tona, e não por mero adorno, mas como liame que reforça a regência adstringente da abstratividade: "O senhor Bauer nem sequer suspeita, portanto, que o judaísmo real, secular e, portanto, também o judaísmo religioso é engendrado constantemente pela vida burguesa atual" e "encontra sua culminação no sistema monetário". Remontando ao cativeiro idealista de Bauer, Marx reafirma que "Ele nem sequer podia suspeitar disso, porque não conhece o judaísmo como parte do mundo real", mas só "como parte de seu mundo, da teologia, porque, na condição de homem devoto e submisso a Deus, não vê o judeu real no judeu ativo", o indivíduo concreto “dos dias de trabalho, mas no santarrão judeu sabático” (MARX, 2003, p. 128). Em suma, a crítica idealista não atina para configuração objetiva da sociabilidade, dos complexos e esferas sociais objetivas, para a vida genérica concreta entificada, para a praticidade da vida burguesa, enfim, para a culminação "judaica” no "sistema monetário"; o ideólogo cativo do Espírito discute os negócios espirituais e sequer suspeita do solo social da religião e do leque das ideatividades.

O neohegeliano exercita-se teologicamente, coloca em parênteses o modo de ser da vida burguesa para sobrepor a ele o judaísmo como "purismo religioso". Doravante, "a emancipação dos judeus para a condição de homens, ou a emancipação humana do judaísmo, não foi considerada, à maneira do senhor Bauer, como sendo uma tarefa especial do judeu", mas, em verdade, "na condição de tarefa prática geral do mundo de hoje, que é um mundo judaico até a raiz". Nesse sentido, "Provou-se que a tarefa da suprassunção [superação] da essência judaica é, na verdade, a tarefa da suprassunção [superação] do judaísmo da sociedade burguesa", isto é, "o caráter inumano da prática de vida atual, cuja culminação é o sistema monetário" (MARX, 2003, p. 129, grifos nossos).

É preciso destacar que Marx não se insere no terreno etéreo da discussão autárquica da religião. Por isso, o autor alemão não é portador de qualquer unilateralismo antissemita, mas um investigador da reprodução material cujas feições "fantásticas” abrolham no terreno teológico-religioso. Na tessitura de sua obra, Marx não quer inferir qualquer negativa à emancipação política dos judeus, e, ainda, é taxativo contra Bauer ao afirmar que o judaísmo não interdita a emancipação política, ou seja, a emancipação política convive com os particularismos. Ao se referir ao judeu, Marx refere-se, sobremaneira, ao particularismo enquistado na sociedade civil, de um lado, e de outro, à figura celestial do cidadão no estado político, uma contradição que se retroalimenta, e que faz do cidadão um servo do indivíduo da sociedade civil-burguesa. A questão, portanto, aparece como uma distinção entre a emancipação política (parcial) e a emancipação humana (radical). O judeu religioso-místico é a figura acendrada do judeu 
prático, existente na malha concreta da vida burguesa. Nesse diapasão, a investidura religiosa, o aroma "teológico" dos judeus é discutido tão somente como manta do baluarte econômico, quer dizer, vai de encontro ao ideário do "povo eleito" não porque questione essa ideologia em seus termos internos, mas porque a explica como necessário social de uma relação prática em que os judeus, perseguidos/restringidos nas diversas sociabilidades, tiveram de inclinar-se, principalmente, aos poros das "atividades comerciais". Com isso, diante da generalização mercantil movida pelo capitalismo, se explicita, mesmo que brevemente, o contexto histórico do qual Marx parte para engendrar sua análise e ilustração.

A questão judaica é para Bauer uma discussão cerrada na religião, constrita na névoa das ideologias, fechada na esgrima do espírito consigo mesmo em busca de sua quintessência. $O$ autor criticado, porta-voz da decrepitude da crítica teológica, pouco se aprofunda nos estranhamentos profanos: trata-se, nesse ínterim, de uma crítica à religião que permanece sob o manto religioso, que discute a religião do ponto de vista da teologia. O Crítico crítico não faz desvelar o mistério do céu com o descortinar do vale de lágrimas (MARX, 2010b) da terra, por isso, a relação da política com a matriz social presente na sociedade civil, assim como a interação recíproca entre religião e a universalidade concreta da vida burguesa desaparece - na cabeça do Crítico. É da emancipação humana que a visão neo-hegeliana, ao mesmo tempo, exige e se afasta: a condição ideal alemã é a condição efetiva dos países clássicos do capitalismo, mas tanto uma e outra são a condição da vitória da abstração, seja no Estado Político Moderno realizado ou na teoria especulativista alemã. Portanto, vitória da abstratividade na reiteração do "estado político acabado", da comunidade do universal abstrato, seja na fraseologia alemã ou no acabamento da sociedade burguesa clássica. O estado político moderno aperfeiçoado, retoma Marx (2010a), se emancipa de todas as particularidades, da afirmação de qualquer privilégio a qualquer grupo religioso, não obstante, torna não-política e natural a própria "vida judaica" em sociedade: o império da vida burguesa.

Logo, em A Sagrada Família, Marx não prescinde da voracidade da crítica da política já realizada, confirmando que a crítica ao especulativismo e a crítica da política são interrelacionadas em seu âmago: o homem da vida burguesa avançada está cindido em cidadão e homem privado, ou citoyen e bourgueois, em suma, entre homem alegórico-abstrato e homem real ao passo que o primeiro é o servo, a sombra do segundo. Em outros termos, a emancipação política porta um teor teológico, um teor religioso porque só emancipa o homem no terreno da abstração, mas nunca na vida social, perpassada pela particularidade, pela contradição, pela dependência, pelo egoísmo, pela contraposição, pelo lucro. Nesse diapasão, o Estado é utilizado por Bauer como um meio de dar fim à religião, abundantemente criticada pelos neo-hegelianos, que ao fazerem isso, levam sua teoria à incompreensão do ser do estado político moderno que é, como atina Marx, a figura religiosa, maximamente religiosa, acabadamente religiosa, da sociabilidade moderna.

Nos “Anais franco-alemães" desenvolveu-se para o senhor Bauer a prova de que essa "humanidade livre" e seu "reconhecimento" não são nada mais do que o reconhecimento do indivíduo burguês egoísta e do movimento desenfreado dos elementos materiais e espirituais que formam o conteúdo de sua situação de vida, o conteúdo da vida burguesa atual; que, portanto, os direitos humanos não liberam o homem da religião, mas apenas lhe outorgam a liberdade religiosa, não o liberam da 
propriedade, mas apenas lhe conferem a liberdade da propriedade, não o liberam da sujeira do lucro, mas, muito antes, lhe outorgam a liberdade para lucrar. (MARX, 2003, p. 132)

A vida burguesa torna-se não-política, torna-se base natural da entificação política em sua figura moderna acabada; com esse assentamento, destarte, em que se apoia o Estado Político Moderno, "Demonstrou-se como o reconhecimento dos direitos humanos por parte do Estado moderno tem o mesmo sentido que o reconhecimento da escravatura pelo Estado antigo". Logo, "assim como o Estado antigo tinha como fundamento natural a escravidão, o Estado moderno tem como base natural a sociedade burguesa e o homem da sociedade burguesa, quer dizer, o homem independente", vincado antissocialmente, "entrelaçado com o homem apenas pelo vínculo do interesse privado e da necessidade natural inconsciente, o escravo do trabalho lucrativo e da necessidade egoísta, tanto da própria quanto da alheia” (MARX, 2003, p. 132).

Essa forma de "humanidade livre" se equaliza, ao fim, como humanidade livre para a vida burguesa. Na pletora dos opróbrios neohegelianos, é a crítica "suntuosa" - renitente contra toda inspeção reta do ser - que decreta os caminhos da liberdade, crítica absoluta que traceja o futuro da emancipação da e para massa. Mas, é a mesma Crítica crítica que não faz senão confirmar ideativamente a contradição geral entre a sociedade civil burguesa e a comunidade do cidadão: a crítica é o espírito e, não por acaso, é na abstratividade da emancipação política que ela se agarra como efetividade correspondente. Sobra, no entanto, "apenas" a vida genérica real:

Porém, assim como a atividade industrial não é superada imediatamente depois de serem superados os privilégios das indústrias, das agremiações e corporações, mas, ao contrário, só depois da superação desses privilégios é que começa a indústria real; assim como a propriedade da terra não é superada imediatamente depois de a posse privilegiada da terra ter sido superada, mas, ao contrário, seu movimento universal começa de fato com a superação de seus privilégios, através do livre parcelamento e da livre alienação; assim como o comércio não é superado com a superação dos privilégios comerciais, mas, ao contrário, passa a se realizar verdadeiramente no livre comércio; assim também a religião apenas se desdobra em sua universalidade prática (basta pensar nos Estados livres da América do Norte) justamente ali onde não existe uma religião privilegiada. (MARX, 2003, p. 134)

As particularidades, o comércio, a indústria, o lucro, a vida civil, não estão mais vinculadas a privilégios políticos: são deixadas livremente, gozam da emancipação política, gozam da entificação universal concreta, ou seja, são o comércio e a religião em sua expressão autêntica, desassombrada, na vida real. O cerne da vida burguesa espalha-se como uma força abrangente e liberada, sem que seja mitigada pelo privilégio político; torna-se base natural da sociabilidade. A sociedade burguesa é a sociedade do homem sem "privilégios", da contradição desenfreada, da mônada egoísta livre para vida privada, da liberdade contra o outro, da religião do privatismo. No estado político acabado, em contraste, o privatismo da religião, isto é, política laicizada como efetivação máxima da religiosidade sui generis da política (MARX, 2010b). Sob esse funcionamento concreto burguês - até onde vai a anatomia da sociedade civil por Marx -, em que a relação capital-trabalho dá o tom, paira o "Estado representativo democrático": culminação da liberdade parcial, "desviante” e possível no âmbito estreito da política. 
A antítese entre o Estado representativo democrático e a sociedade burguesa é a culminação da antítese clássica entre a comunidade pública e a escravidão. No mundo moderno, todos são, a um só tempo, membros da escravidão e da comunidade. Precisamente a escravidão da sociedade burguesa é, em aparência, a maior liberdade, por ser a independência aparentemente perfeita do indivíduo, que toma o movimento desenfreado dos elementos estranhados de sua vida, já não mais vinculados pelos nexos gerais nem pelo homem, por exemplo, o movimento da propriedade, da indústria, da religião etc., por sua própria liberdade, quando na verdade é, muito antes, sua servidão e sua falta de humanidade completas e acabadas. O privilégio é substituído aqui pelo direito. (MARX, 2003, p. 135)

No que concerne à obra A Ideologia Alemã, pode-se vislumbrar a confirmação da solerte crítica de Marx aos estranhamentos, não apenas aos "celestes", mas aos "profanos", tendo em conta que o "enigma" se resolve com a crítica teórica e o dilaceramento prático da "vida terrena", solo social de onde emergem necessidades e possibilidades para surgir, para gênese das demais práxis sociais. Retomando as Teses sobre Feuerbach do autor comunista, tem-se explicação refulgente em sua IV Tese em que se lê: "Feuerbach parte do fato da auto-alienação religiosa, do desdobramento do mundo em um mundo religioso, imaginário, e outro real". Dessa feita, "Sua tarefa consiste em decompor o mundo religioso em sua base terrena. Não vê que, uma vez realizado esse trabalho, o principal continua por fazer", remetendo, como outrora havíamos afirmado, que a partir de 1845, Marx passa à aproximação de Feuerbach com os demais erráticos jovens hegelianos. Doravante, "Na realidade, o fato de que a base terrena se separe de si mesma e fixe nas nuvens um reino independente só pode ser explicado através da dilaceração interna e da contradição desse fundamento terreno consigo mesmo". Logo, "Este último deve, portanto, primeiro ser compreendido em sua contradição e em seguida revolucionado praticamente mediante a eliminação da contradição". Finalmente, "depois de descobrir, por exemplo na família terrena o segredo da sagrada família, é preciso criticar teoricamente aquela e transformá-la praticamente” (MARX, 2007, p. 534).

Como fica claro, Marx não é um mero crítico gnosiológico. Não sustenta simplesmente a correção teórica, teológica da religião, nem o apontamento pueril e descompromissado da fragilidade do intelecto político. $\mathrm{O}$ autor em tela avança cientificamente querendo demonstrar as raízes interativas, gregárias, que em sua especificidade demandam as práxis sociais enformadoras de ilusões socialmente necessárias. Não se trata, como dissemos linhas acima, de uma esgrima cultural autárquica, isto é, de uma luta pela quintessência do espírito, mas do conhecimento correto da sociedade que precisa ser revolucionada, desde sua matriz, a sociedade civil-burguesa, a legalidade imanente do complexo econômico em questão e, portanto, das demais atividades humanas vincadas à reprodução dessa sociedade, particularizada em distintas entificações do capitalismo. Dessa feita, Marx é incisivo contra os que pretendem, no prumo de um orgulhoso idealismo, libertar o "homem", emancipá-lo pelo evolver da autoconsciência; falha subjetivista ou hipóstase da subjetividade, pois que prescinde de meios materiais que são os únicos efetivadores e o único âmbito onde o homem pode de fato ser emancipado.

Nem lhes explicaremos que só é possível conquistar a libertação real [wirkliche Befreiung] no mundo real e pelo emprego de meios reais; que a escravidão não pode ser superada sem a máquina a vapor e a Mule-Jenny, nem a servidão sem a melhora da agricultura, e que, em geral, não é possível libertar os homens enquanto estes forem incapazes de obter alimentação e bebida, habitação e vestimenta, em qualidade e quantidade adequadas. (MARX, 2003, p. 29) 
O trecho estabelecido é enfático na prioridade ontológica da produção e reprodução material do ser social, logo, é imediato apropriar-se de que a libertação do homem, em sua autêntica alusão e efetividade, é a libertação real das cadeias reais, do modo de produção e reprodução material da vida, e só nesse sentido, da pletora de estranhamentos edificada no concerto dessa vida genérica concreta. Em suma, “a libertação é um ato histórico e não um ato de pensamento” (MARX, 2003, p. 29), embora o pensamento reto - em relação aos nexos e relações sociais enfrentadas - seja uma potência subjetiva de fundamental operatividade na práxis social reconfiguradora e dissolutora da cadeia da autolienação e estranhamentos.

Marx, dessa feita, não lavra um materialismo incipiente que implante uma imputação antihumanista à realidade, como ocorre naquele que separa subjetividade (passiva) e objetividade como exterioridades completamente desligadas. A mundanidade, a objetividade é, para Feuerbach, apenas um mundo sensível separado do homem, que se coloca a despeito de qualquer transitividade subjetividadeobjetividade, prescindindo do verdadeiro apanágio da subjetividade ativa, quer dizer, da atividade sensível (MARX, 2007). Nessa circunscrição materialista incipiente feuerbachiana, o homem é representado como o ser da ideação e da intuição, e não o ser consciente que faz mundo e se autofaz, que age sobre complexos objetivos dotados de nexos e relações. A atividade humana é atividade de abstração, ideação, segundo o débil materialismo que Marx ultrapassa, evidenciando a mácula idealista da qual está inerentemente cativo.

Se Feuerbach não se consagra a entender a objetividade social como produto histórico de indivíduos coletivamente ativos, como respostas práticas - mais ou menos conscientes - dadas pelos homens às suas contradições e conflitos societários, o autor de $\mathbf{O}$ capital é suficientemente sagaz ao tecer o exemplo de que "Como se sabe, a cerejeira, como quase todas as árvores frutíferas, foi transplantada para nossa região pelo comércio, há apenas alguns séculos e, portanto", ironiza "foi dada à 'certeza sensível' de Feuerbach apenas mediante essa ação de uma sociedade determinada numa determinada época" (MARX, 2007, p. 31). Se o materialista imberbe não concebe a atividade sensível, sua tônica efetivadora, prática, mas apenas o homem passivo, intuitivo, intelectivamente ativo, unicamente ativo como ser que pensa, logo, não pode chegar à fulcral imbricação ontológica entre subjetividade e objetividade, vitimando sua filosofia com o mesmo brio e vaticínio místico dos demais autores criticados por Marx. Em refulgente súmula, "Na medida em que Feuerbach é materialista, nele não se encontra a história, e na medida em que toma em consideração a história ele não é materialista” (MARX, 2007, p. 32).

Com essas elucubrações, as críticas ao especulativismo e à politicidade demonstram novamente sua interrelação, isto é, emprestam a clareza de que a consciência invertida é fruto da vida invertida, como Marx já asseverara em sua Introdução em 1844. Conforme angaria-se estabelecer, é o modo de ser da junção material entre os homens que matriza uma gregaridade ou interatividade, antes mesmo de qualquer "absurdo" posto pelos "intelectos invertidos" emergentes, pelas formas ideológicas que emergem daquela tessitura; logo, para o nosso autor, embora o protagonismo das esferas ideológicas não possa ser menosprezado, como se pode constatar em diferentes formas de ser o peso reprodutivo da política ou da religião, não são tais elementos a condição basilar da sociabilidade e, com isso, "Mostra-se, portanto, 
desde o princípio, uma conexão materialista dos homens entre si”, quer dizer, "conexão que depende das necessidades e do modo de produção e que é tão antiga quanto os próprios homens", enfim, "uma conexão que assume sempre novas formas e que apresenta, assim, uma 'história', sem que precise existir qualquer absurdo político ou religioso que também mantenha os homens unidos" (MARX, 2007, p. 34).

Nesse diapasão, Marx esmiúça o processo pelo qual, na divisão social do trabalho, se objetiva a "condição que necessita de ilusões", isto é, a forma de ser teratológica e heterodeterminada da vida dos indivíduos sob o jugo da relação-capital, ou seja, relação estranhada com sua atividade vital, na qual a atividade produtiva abrolha e se reproduz como práxis subsumida a um poder estranho. Interatividade dilapidadora, oficina de indivíduos depauperados, condição que lhes aparece como necessidade e sacrifício para sobreviver, perniciosa conjuração de "forças desconhecidas" que os opõe e interdita. A alegoria marxiana é esclarecedora:

ao passo que, na sociedade comunista, onde cada um não tem um campo de atividade exclusivo, mas pode aperfeiçoar-se em todos os ramos que lhe agradam, a sociedade regula a produção geral e me confere, assim, a possibilidade de hoje fazer isto, amanhã aquilo, de caçar pela manhã, pescar à tarde, à noite dedicar-me à criação de gado, criticar após o jantar, exatamente de acordo com a minha vontade, sem que eu jamais me torne caçador, pescador, pastor ou crítico. Esse fixar-se da atividade social, essa consolidação de nosso próprio produto num poder objetivo situado acima de nós, que foge ao nosso controle, que contraria nossas expectativas e aniquila nossas conjeturas, é um dos principais momentos no desenvolvimento histórico até aqui realizado. O poder social, isto é, a força de produção multiplicada que nasce da cooperação dos diversos indivíduos condicionada pela divisão do trabalho, aparece a esses indivíduos, porque a própria cooperação não é voluntária mas natural, não como seu próprio poder unificado, mas sim como uma potência estranha, situada fora deles, sobre a qual não sabem de onde veio nem para onde vai, uma potência, portanto, que não podem mais controlar e que, pelo contrário, percorre agora uma sequência particular de fases e etapas de desenvolvimento, independente do querer e do agir dos homens e que até mesmo dirige esse querer e esse agir. (MARX, 2007, p. 38)

A divisão do trabalho à qual se refere acima aparece como poder estranho, força incontrolável, torvelinho que suga as forças dos homens; por conseguinte, trabalho ou atividade vital que interdita a objetivação omnilateral dos indivíduos (como advoga a sobredita imagem marxiana), onde "as condições sob as quais determinadas forças de produção podem ser utilizadas são as condições da dominação de uma determinada classe da sociedade, cujo poder social", demarca-se, "derivado de sua riqueza, tem sua expressão prático-idealista na forma de Estado existente em cada caso". Logo, "é essa a razão pela qual toda luta revolucionária dirige-se contra uma classe que até então dominou". Ademais, mote de nossa questão, "em todas as revoluções anteriores a forma da atividade permaneceu intocada, e tratava-se apenas de instaurar uma outra forma de distribuição dessa atividade", ou seja, "uma nova distribuição do trabalho entre outras pessoas, enquanto a revolução comunista volta-se contra a forma da atividade existente até então", que, portanto, deve dilacerar a universalidade concreta em que os indivíduos são títeres de uma lógica específica que se apresenta como um autômato. Portanto, retomando o pensamento marxiano, ("revolução comunista") que "suprime o trabalho e supera [aufhebt] a dominação de todas as classes ao superar as próprias classes, pois essa revolução é realizada pela classe que, na sociedade, não é mais considerada como uma classe, não é reconhecida como tal”, sendo, nessa configuração, “já a expressão da dissolução de todas as classes, nacionalidades etc., no interior da sociedade atual” e, por fim, "tanto para a 
criação em massa dessa consciência comunista quanto para o êxito da própria causa faz-se necessária uma transformação massiva dos homens", o que, por sua vez, "só se pode realizar por um movimento prático" (MARX, 2007, p. 42).

Marx, dessa feita, instaura uma apreensão longe de qualquer unilateralidade economicista, politicista ou idealista de qualquer monta. Afere a realidade efetiva, assim como sua proposta de reconfiguração é perimetrada pelos respectivos delineamentos filosóficos e particularizações científicas galgadas em árdua atividade teórica sobre o concretamente existente, sem arrimos apriorísticos. O autor não aduz sobre qualquer inoperância, inefetividade, caráter epifenomênico da consciência ou da própria práxis social política, mas confere a existência dos diferentes complexos sociais, especificidades, articulações e reciprocidades, sempre tendo por assertiva geral (ponto de partida da atividade de adensamento científico), a base real que sustenta o múltiplo novelo de práxis sociais de uma sociedade determinada. É por isso que, no autor de A Ideologia Alemã, a crítica ao estado não pode cultivar anódinos tão em voga, que esbulham o escrutínio do ser-precisamente-assim do estado e da política.

Essa concepção da história consiste, portanto, em desenvolver o processo real de produção e a partir da produção material da vida imediata e em conceber a forma de intercâmbio conectada a esse modo de produção e por ele engendrada, quer dizer, a sociedade civil em seus diferentes estágios, como o fundamento de toda a história, tanto a apresentando em sua ação como Estado como explicando a partir dela o conjunto das diferentes criações teóricas e formas da consciência - religião, filosofia, moral etc. etc. - e em seguir o seu processo de nascimento a partir dessas criações, o que então torna possível, naturalmente, que a coisa seja apresentada em sua totalidade (assim como a ação recíproca entre esses diferentes aspectos) (MARX, 2007, p. 42)

Marx reitera a comunidade da política como "comunidade aparente", e ademais, ativa na medida em que corolário da "associação de uma classe contra outra classe", ou seja, "ação" da sociedade civil "como Estado". Também, o que se desdobra é que o processo da emancipação política, lapidação da comunidade do cidadão, não deixa de ser uma "comunidade totalmente ilusória" para as classes dominadas, pois é ainda "entrave" ou uma comunidade contra a classe explorada. De outra forma, confirma-se a estreiteza da liberdade abstratamente afirmada em longínquos paradeiros políticos, frutificação específica das renovadas relações sociais classistas de produção e intercâmbio, da interatividade entre os homens ativos que produzem a vida de modo determinado.

A transformação, pela divisão do trabalho, de forças (relações) pessoais em forças reificadas não pode ser superada arrancando-se da cabeça a representação geral dessas forças, mas apenas se os indivíduos voltarem a subsumir essas forças reificadas a si mesmos e superarem a divisão do trabalho. Isso não é possível sem a comunidade. É somente na comunidade [com outros que cada] indivíduo tem os meios de desenvolver suas faculdades em todos os sentidos; somente na comunidade, portanto, a liberdade pessoal torna-se possível. Nos sucedâneos da comunidade existentes até aqui, no Estado etc., a liberdade pessoal existia apenas para os indivíduos desenvolvidos nas condições da classe dominante e somente na medida em que eram indivíduos dessa classe. A comunidade aparente, em que se associaram até agora os indivíduos, sempre se autonomizou em relação a eles e, ao mesmo tempo, porque era uma associação de uma classe contra outra classe, era, para a classe dominada, não apenas uma comunidade totalmente ilusória, como também um novo entrave. $\mathrm{Na}$ comunidade real, os indivíduos obtêm simultaneamente sua liberdade na e por meio de sua associação. (MARX, 2007, p. 64) 
Nesse ínterim, avancemos e vejamos como Marx define o burilamento da sociedade civil ligada ao desenvolvimento das relações burguesas, onde as relações econômicas apresentam-se de modo inadvertido e desgarrado das brumas de qualquer romantismo: "A sociedade civil abarca o conjunto do intercâmbio material dos indivíduos no interior de um estágio determinado das forças produtivas", outrossim, "Ela abarca o conjunto da vida comercial e industrial de um estágio e, nessa medida, ultrapassa o Estado e a nação, apesar de, por outro lado, ela ter de se afirmar ante o exterior como nacionalidade e se articular no interior como Estado". Estado que, segundo a assertiva, aparece como afirmação "interna" da sociedade civil burguesa, enquanto a "nacionalidade" como sua afirmação "externa"; ainda, "A palavra sociedade civil [bürgerliche Gesellschaft] surgiu no século XVIII, quando as relações de propriedade já haviam se libertado da comunidade antiga e medieval". Com isso, desimpedida em seu exercício, "A sociedade civil, como tal, desenvolve-se somente com a burguesia", mas "com este mesmo nome, no entanto, foi continuamente designada a organização social que se desenvolve diretamente a partir da produção e do intercâmbio" a qual "constitui em todos os tempos a base do Estado e da restante superestrutura idealista” (MARX, 2007, p. 74).

A sociedade civil-burguesa é o atilamento da separação, o acabamento da demarcação entre as esferas econômica e a comunidade do estado, outrossim, do cidadão, da vida genérica abstrata, do universal abstrato ante a vida genérica concreta. Anteriormente, comunidade política e relações econômicas configuravam-se de modo imiscuído, de modo tal que escravos e servos fossem imediatamente rebaixados da comunidade política pela sua posição na urdidura da vida real. A comunidade do cidadão se separa, pois, na figura desenvolvida do "estado político acabado", onde viceja o direito do cidadão, centro da comunidade separada, todavia, emanação da sociedade civil em teor abstratoformal. A economia burguesa, portanto, está pressuposta e "emancipada" para se reproduzir, ao mesmo tempo em que o estado moderno desenvolvido, em autonomia relativa, ainda é forma política das necessidades da burguesia, das contradições intrínsecas à sociedade do capital, sendo ainda uma "comunidade aparente" contra a classe explorada, e não, como quer Marx, a "comunidade real, [onde] os indivíduos obtêm simultaneamente sua liberdade na e por meio de sua associação”. Em suma, a própria formalidade ou abstração do estado moderno, cuja virtude e obliquidade (teor teológico-religioso) são consideradas por Marx, carrega certo grau manipulatório, pois pressupõe a vida da sociedade civilburguesa, a toma como intercâmbio insuperável, eclipsando e limitando a resolução das contradições sobre as quais está assentada, enfim, "forma de organização que os burgueses se dão necessariamente, tanto no exterior como no interior, para a garantia recíproca de sua propriedade e de seus interesses" (MARX, 2007, p. 75).

Entre os povos originados da Idade Média, a propriedade tribal desenvolve-se passando por diferentes fases - propriedade feudal da terra, propriedade mobiliária corporativa, capital manufatureiro - até chegar ao capital moderno, condicionado pela grande indústria e pela concorrência universal, quer dizer, até chegar à propriedade privada pura, que se despiu de toda aparência de comunidade e suprimiu toda influência do Estado sobre o desenvolvimento da propriedade. A essa propriedade privada moderna corresponde o Estado moderno, que, comprado progressivamente pelos proprietários privados por meio dos impostos, cai plenamente sob o domínio destes pelo sistema de dívida pública, e cuja existência, tal como se manifesta na alta e na baixa dos papéis 
estatais na bolsa, tornou-se inteiramente dependente do crédito comercial que lhe é concedido pelos proprietários privados, os burgueses. A burguesia, por ser uma classe, não mais um estamento, é forçada a organizar-se nacionalmente, e não mais localmente, e a dar a seu interesse médio uma forma geral. Por meio da emancipação da propriedade privada em relação à comunidade, o Estado se tornou uma existência particular ao lado e fora da sociedade civil; mas esse Estado não é nada mais do que a forma de organização que os burgueses se dão necessariamente, tanto no exterior como no interior, para a garantia recíproca de sua propriedade e de seus interesses (MARX, 2007, p. 75)

No núcleo do desvelamento das articulações entre estado e sociedade civil-burguesa, o autor de Trier ainda reflete sobre a inversão manipulatória existente no complexo do estado e na esfera do direito, na medida em que apresentam como práxis demiúrgicas e autárquicas, sendo, por isso mesmo, aspectos sociais prenhes de uma "ilusão". O vínculo entre estado e dominação de classes fica claro, como fica explícito também que estado e complexo da cultura não podem ter uma história própria, mas, sobretudo, um evolver intrínseco à determinada totalidade articulada, que tem como base o complexo econômico, logo: "Como o Estado é a forma na qual os indivíduos de uma classe dominante fazem valer seus interesses comuns e que sintetiza a sociedade civil inteira de uma época", tem-se que "todas as instituições coletivas são mediadas pelo Estado, adquirem por meio dele uma forma política. Daí a ilusão, como se a lei se baseasse na vontade e, mais ainda, na vontade separada de sua base real [realen], na vontade livre". O "pensamento invertido" ou manipulatório deriva da própria "contradição terrena" e "Do mesmo modo, o direito é reduzido novamente à lei". Assim, "O direito privado se desenvolve simultaneamente com a propriedade privada, a partir da dissolução da comunidade natural", ademais, "Entre os romanos, o desenvolvimento da propriedade privada e do direito privado não gerou consequências industriais e comerciais, pois o seu modo de produção inteiro manteve-se o mesmo". Todavia, "Entre os povos modernos, em que a comunidade feudal foi dissolvida pela indústria e pelo comércio, o nascimento da propriedade privada e do direito privado deu início a uma nova fase, suscetível de um desenvolvimento ulterior (...)". Nesse contexto de gênese burguesa, "Tão logo a indústria e o comércio desenvolveram a propriedade privada, primeiro na Itália e mais tarde noutros países, o desenvolvido direito privado romano foi imediatamente readotado e elevado à posição de autoridade". Ainda, "Quando, mais tarde, a burguesia conquistou poder suficiente para que os príncipes acolhessem seus interesses a fim de, por meio da burguesia, derrubar a nobreza feudal", efetivou-se “em todos os países - na França, no século XVI - o desenvolvimento propriamente dito do direito, que, com exceção da Inglaterra, teve como base o Código Romano". O autor ainda acrescenta, "Também na Inglaterra os princípios do direito romano tiveram de ser introduzidos para o ulterior desenvolvimento do direito privado (particularmente no âmbito da propriedade mobiliária)" (MARX, 2007, p. 76). Logo:

Essa ilusão jurídica, que reduz o direito à mera vontade, resulta necessariamente, no desenvolvimento ulterior das relações de propriedade, no fato de que alguém pode ter um título jurídico de uma coisa sem ter a coisa realmente. Se, por exemplo, a renda de um lote de terra é eliminada pela concorrência, o proprietário do lote conserva, sem dúvida alguma, o seu título jurídico, juntamente com o jus utendi et abutendi. Mas ele não poderá empreender nada e não possuirá nada como proprietário rural, caso não disponha de capital suficiente para cultivar sua terra. A partir dessa mesma ilusão dos juristas explica-se que, para eles e para todos os códigos jurídicos em geral, seja algo 
acidental que os indivíduos estabeleçam relações uns com os outros, contratos por exemplo, que essas relações sejam consideradas como relações que [podem] ser estabelecidas ou não a depender da vontade, e cujo conteúdo [rep]ousa inteiramente sobre o [arb]ítrio individual dos contratantes. Sempre que, por meio do desenvolvim[ento] da indústria e do comércio, surgiram novas formas de [in]tercâmbio, [por] exemplo companhias de seguros etc., o direito foi, a cada vez, obrigado a admitilas entre os modos de adquirir a propriedade (MARX, 2007, p. 77).

Em linha com o que foi estabelecido, nas anotações esparsas de Marx, se encontram ainda sentenças que vão ao encontro das formulações sobreditas como " $\mathrm{Na}$ lei, os burgueses devem fornecer uma expressão geral de si mesmos, precisamente porque dominam como classe". Em seguida, "Não há história da política, do direito, da ciência etc., da arte, da religião etc.”, ao passo que na própria forja ideológica constitui-se em uma inversão: "Por que os ideólogos colocam tudo de cabeça para baixo. Religiosos, juristas, políticos, juristas, políticos (homens de Estado, em geral), moralistas”. Mais à frente, “autonomização dos negócios por meio da divisão do trabalho; cada um toma o seu próprio ofício como o verdadeiro ofício". Nessa malha societária, "No que diz respeito à relação entre seu ofício e a realidade, eles criam ilusões tão mais necessárias quanto isso já é condicionado pela própria natureza do ofício”. Ou seja, vê-se que se trata de uma articulação objetiva e não de mero desvio subjetivista, de forja ideológica ilusória que não possui autarquia, autonomia absoluta, mas interconexão com as demandas intrínsecas de uma base produtiva específica. Ainda, "As relações, na jurisprudência, na política, convertem-se - em conceitos na consciência"; contudo, "por não estarem acima dessas relações, os conceitos dessas relações são, na cabeça de religiosos, juristas, políticos e moralistas, conceitos fixos”, logo, “o juiz, por exemplo, aplica o código, e por isso a legislação vale, para ele, como o verdadeiro motor ativo". Trata-se de "conceitos de consciência", "conceitos fixos", que carregam, na própria trama ontoprática reprodutiva da sociabilidade do capital, uma "Ideia do direito. Ideia do Estado. Na consciência comum, a questão é colocada de cabeça para baixo"; da mesma forma, "A religião é, desde o início, a consciência da transcendência que provém dos poderes reais". Resta claro, práxis sociais “superestruturais" que invertem - ideativamente - o peso determinativo do terreno econômico, que se apresentam como absolutamente autônomas e movedoras por excelência da vida societária, ao passo que, em verdade, eclipsam o fato de que, a despeito de sua especificidade, dimanam da base material dos indivíduos interativos. Como arremate que retoma a chave do "enigma" na contradição da "vida terrena", vê-se que "Os indivíduos sempre partiram de si mesmos, sempre partem de si mesmos. Suas relações são relações de seu processo real de vida. Como ocorre que suas relações venham a se tornar autônomas em relação a eles?”, ou seja, “Que os poderes de sua própria vida se tornem superiores a eles? Em uma palavra: a divisão do trabalho, cujo grau depende sempre do desenvolvimento da força produtiva”. Essas são as repostas marxianas que, se não estabelecem desde já toda concreção à qual o autor chegaria em sua obra futura, não olvida as necessidades e possibilidades que emergem da base real, o elo tônico articulador, sobre o qual as diversas atividades humanas efetivam a relação "homem-homem", logo, as ideações e as atividades sensíveis concatenadas de uma época e lugar, de um modo de produção.

\section{Considerações Finais}


Com o que fica afirmado no breve texto, não se permite, a não ser como ilação inconsequente e/ou mal intencionada, qualquer interpretação em prol do afastamento peremptório e grosseiro da atuação política. O mesmo vale para obra inspiradora e rigorosa de J. Chasin que, vítima do rompante crítico inconsequente, foi atacada por taxativas infundadas (por vezes, mendazes) de "apoliticismo", a partir de intérpretes em miniatura do marxismo, que não poderiam fornecer senão uma crítica de igual estatura. Basta, para não citarmos a lavra vastíssima e bastante cuidadosa com o terreno político de A Miséria Brasileira, trazer, de passagem, a seminal diferenciação proposta pelo filósofo marxista brasileiro em A "Politicização" da Totalidade: Oposição e Discurso Econômico, na qual se vê que "Radicalmente distinto também é do ato de politizar, que implica em partir de uma equação da totalidade, conceitualmente elaborada. Ao inverso, o discurso politicizado da oposição é a diluição, o desossamento do todo”, quer dizer, "a sua liquefação em propostas abstratamente situadas apenas no universo das regras institucionais". Politicizar, ao inverso de politizar, manejo consciente da luta tática política levada aos limites e, sempre, informada pela luta estratégica econômica radical, é "Inobservância que, justamente por destacar, isolar e hiperacentuar o 'político', despolitiza, na exata medida que desliga o político da raiz que o engendra e reproduz"; em outras palavras, "na exata medida que o desqualifica enquanto político real, enquanto dimensão de um todo, que só pelo todo possui especificidade", e assim, "do qual não faz sentido dizer que guarda autonomia, como se fora um cartão destacável de um fichário de folhas soltas, passível de infinitos "embaralhamentos"” ao gosto de âmagos e volúpias idealistas de mudança. Esgarçando ainda mais as rebaixadas e natimortas acusações de "apoliticismo", vê-se: "A autonomização do político e sua consequente hiperacentuação é, de fato, seu esvaziamento numa entidade abstrata, a perda de sua concretude, e decorrentemente de sua potência e eficácia”. Para endossar, por fim, a adensada diferenciação (com a qual evocamos a leitura das obras sobreditas de J. Chasin), "a politicização da totalidade pelo discurso é pelo menos um grosseiro gesto simplificador que, no mínimo, desconhece, desrespeita e/ou elimina a qualidade própria das demais componentes que integram a totalidade" (CHASIN, 1977, p. 146-147). Para aferrar nossa posição, voltemos ao próprio Marx, neste fechar de cortinas, expondo excerto de um texto severamente clarificador, as Glosas de 44, a despeito de infelicitarse por obra negligenciada, talvez mesmo, pelo respectivo qualificativo luminoso.

Contudo, a comunidade, em relação à qual o trabalhador está isolado, possui uma realidade e uma dimensão bem diferentes daquelas que são próprias da comunidade política. Essa comunidade, da qual o seu próprio trabalho o separa, é a vida mesma, a vida física e espiritual, a moralidade humana, a atividade humana, o usufruto humano, a condição humana. A condição humana [menschliches Wesen] é a verdadeira comunidade dos humanos [Gemeinwesen der Menschen]. O funesto isolamento em relação a essa condição é incomparavelmente mais abrangente, mais insuportável, mais terrível e mais contraditório do que o isolamento em relação à comunidade política; na mesma proporção, a eliminação desse isolamento e até mesmo uma reação parcial a ele, uma revolta contra ele, tem um alcance infinitamente maior, assim como o ser humano é infinitamente maior do que o cidadão e a vida humana é infinitamente maior do que a vida política. (MARX, 2010b, p. 50) 
Referências:

ALBINATI, A. J. Chasin: a ontonegatividade da politicidade em Marx. Revista Verinotio, n. 9, ano V, p. 47-61, 2008

CHASIN, J. A "politicização" da totalidade: oposição e discurso econômico. Revista Temas de Ciências Humanas, n. 2, p.145-178, 1977.

CHASIN, J. A sucessão na crise e a crise na esquerda. Disponível em: https://marxists.architexturez.net/portugues/chasin/1989/mes/crise.pdf Acesso em: 12 fev 2021

CHASIN, J. Marx - a determinação ontonegativa da politicidade. Revista Verinotio. n. 15, ano VIII, p. 42-59, 2012.

CHASIN, J. Marx: estatuto ontológico e resolução metodológica. São Paulo: Boitempo, 2019

CHASIN, J. Rota e prospectiva de um projeto marxista. Revista Ad Hominem. Tomo III: Política. São Paulo: Estudos e Edições Ad Hominem, 2001.

ENDERLE, R. Ontologia e política: a formação do pensamento marxiano de 1842 a 1846. 2000.

Orientador: José Chasin/Ester Vaisman. 151. (dissertação) - Universidade Federal de Minas Gerais, Belo Horizonte, 2000.

MARX, K.; ENGELS, F. A ideologia alemã. São Paulo: Boitempo, 2007.

MARX, K.; ENGELS, F. A sagrada família. São Paulo: Boitempo, 2003.

MARX, K. Lutas de classes na Alemanha. São Paulo: Boitempo, 2010b.

MARX, K. Manuscritos econômico-filosóficos. In: COSTA, M. A Diferença entre as categorias Lebensäusserung, Entäusserung, Entfremdung e Veräusserung nos Manuscritos Econômicofilosóficos de Karl Marx de 1844. 1999. Orientador: Ester Vaisman. 177. (dissertação) - Universidade Federal de Minas Gerais, Belo Horizonte, 1999.

MARX, K. Sobre a questão judaica. São Paulo: Boitempo, 2010a.

SARTORI, V. Direito, política e reconhecimento: apontamentos sobre Karl Marx e a crítica ao direito. Revista da Faculdade de Direito - UFPR, v. 61, n. 2, p. 203-233, 2016.

SILVA, S. A crítica da razão política revisitada. Revista Verinotio. n. 15, ano VIII, p. 3-14, 2013

Nota

1 Sociólogo, Mestre e Doutorando em Estudos Organizacionais, Trabalho e Sociedade pela Universidade Federal de Minas Gerais (UFMG), com bolsa CAPES. E-mail: rickcoelholda@hotmail.com. https://orcid.org/0000-0003-3657-1414" https://orcid.org/0000-0003-3657-1414 